\section{Англійська література}

\section{English literature}

ISSN: 2411-6181(on-line); ISSN: 2311-9896 (print)

Current issues of social studies and history of medicine. Joint Ukrainian-Romanian scientific journal, 2018, №:3(19), P. 93-97 UDK 821.111-31Д. Л. 09

DOI 10.24061/2411-6181.3.2018.67

\author{
КОНЦЕПТУАЛЬНІСТЬ МІФОЛОГІЧНОГО ПРОСТОРУ \\ В ДИЛОГІЇ ДОРІС ЛЕССІНГ «МААРА І ДАНН» \\ ОЛена КРАВЕЦЬ, Наталія ПРОСКУРІНА, \\ Харківський національний університет \\ імені В. Н. Каразіна, Харків (Україна) \\ kravets.helen.fil@gmail.com; amentina@i.ua
}

\author{
FEATURES OF THE MYTHOLOGICAL SPACE IN \\ DORIS LESSING'S DILOGY "MARA AND DANN" \\ Olena KRAVETS, Nataliia PROSKURINA \\ Kharkiv V. N. Karazin National University Kharkiv (Ukraine), \\ ORCID ID 0000-0001-7428-8535
}

Кравец Е., Проскурина Н. Концептуальность мифологического простора в дилогии Д. Лессинг «Маара и Данн». Статья посвящена изучению литературного наследия современной английской писательницы, Нобелевского лауреата, Дорис Лессинг. Творчество автора представляет собой сложное литературное явление, которое исследователи связывают с канонами постмодернистской литературы. Объектом литературоведческого анализа являются романы «Маара и Данн», «Повесть о генерале Данная, дочери Маары, Гриоте и снежном псе», которые относятся к позднему периоду творчества Д. Лессинг. Цель статьи - исследовать мифологические черты художественного пространства и времени, которые определяют авторскую концепцию художественной картины мира в дилогии. Специфика исследуемого материала и характер поставленных задач обусловили необходимость применения комплекса методов: культурно-исторического метода, который сделал возможным определение факторов влияния на творчество автора в контексте эпохи; структурно-семантический метод, который позволил исследовать особенности воплощения категорий времени и пространства в романах; мифокритический подход актуализирован для определения мифологических елементов и специфики образной системы в дилогии «Маара и Данн». В результате анализа романов Д. Лессинг сделаны выводы, что мифологическому пространству романов писательницы присущи гетерогенные характеристики, которые актуализируются через такие бинарные оппозиции, как «север-юг», «живой-мертвый», «сакральный-профанный», «опасный-безопасный», «правый-левый», «открытый-закрытый». Хронотоп второй части дилогии, «Повесть о генерале Данная, дочери Маары, Гриоте и снежном псе», отличается от пространственно-временного континуума первого романа. Бинарные оппозици «север-юг» проявляются в нем более имплицитно, отсутствует резкий контраст в изображении топосов, характерный для первой части дилогии. Хронотопу обеих частей дилогии присуща циклическая концепция времени, характерная для мифологической традиции. Романные события происходят в далеком постапокалиптическом будущем, на территории континента Ифрик после глобальной катастрофы, которая уничтожила все достижения культуры и остановила развитие человечества. Главные герои дилогии Д. Лессинг оказываются в «закрытом» пространстве континента, они вынуждены искать сакральный центр мироздания, чтобы восстановить утерянные знания поколений и вернуть власть над миром, пройти процесс «индивидуации» с целью обретениия «самости». Научная новизна исследования заключается в том, що осуществлен комплексный анализ пространственно-временных категорий дилогии Д. Лессинг, а также виявлена структурообразующая функция художественного времени в романах. Анализ мифологических аспектов дилогии писательницы углубит понимание специфики художественного мира Д. Лессинг, творчество которой отображает неомифологические тенденции английской литературы XX-XXI столетий, а также наметит векторы дальнейшего изучения произведений современныХ англо-американских писателей, в творчестве которых прослеживаются неомифологические черты.

Ключевые слова: Д. Лессинг, неомифологизм, художественное пространство, художественное время, роман.

Постановка проблеми та її зв'язок із важливими науковими завданнями. Творчість сучасної англійської письменниці Доріс Лессінг (Doris Lessing, 1919 2013), лауреата Нобелівської премії 2007 року, постає як складне літературне явище, яке дослідники пов'язують із канонами постмодерністської літератури й класики феміністичного роману.

Одним із основних векторів сучасних досліджень творчої спадщини письменниці $є$ феміністичний аспект. Зокрема, такі зарубіжні літературознавці, як Г. Блум, Г. Грін, Л. Скотт, Ф. Перракіс вважають письменницю неперевершеною майстринею зображення внутрішнього світу жіночих образів. Глибокий психологізм творчості Д. Лессінг, особлива творча манера постмодерністського письма авторки є предметом дослідження також i вітчизняних вчених, серед яких: М. Горлач, Л. Мірошниченко, В. Крамар, В. Савина, І. Шаповалова.

Проте вивчення значної кількості наукових праць дозволяє зробити висновок, що поза увагою дослідників i досі залишаються романи письменниці «Маара i Данн», «Повість про генерала Данна, дочку Маари, Гріота та сніжного пса». Д. Лессінг. Аналіз міфологічних аспектів означених творів поглибить розуміння авторської концепції й специфіки художнього світу письменниці, яка $є$ однією $з$ визначних представниць англійської літератури XX - XXI ст., у творчості якої відобразились неоміфологічні тенденції цієї доби, а також визначить перспективи вивчення сучасної англійської літератури, що зумовлює актуальність дослідження.

Аналіз останніх досліджень і публікацій, у яких започатковано розв'язання проблеми. У вітчизняному науковому дискурсі виявлено такі основні напрями вивчення літературної спадщини Д. Лессінг, як: 1) психологічний підхід (М. Горлач, І. Зимомря, В. Луцик, М. Миколайчик); 2) визначення особливостей художнього мислення письменниці в аспекті фемінізму (Л. Мірошниченко, В. Савина, І. Шаповалова); 3) аналіз соціально-політичних аспектів творчості (Л. Мірошниченко, А. Шпиталь); 4) дослідження поетики творів Д. Лессінг (М. Горлач, В. Крамар); 5) виявлення типологічних зв'язків літературної спадщини письменниці в культурно-історичному контексті (М. Горлач, В. Луцик, Л. Мірошниченко); 6) визначення творчого методу письменниці (О. Подкоритова); 
7) паратекстуальний підхід (Л. Мірошниченко).

У зарубіжному літературознавстві вирізняються такі основні підходи дослідження романів письменниці, як: 1) феміністичний аспект (Г. Блум, Л. Скотт); 2) історичний аспект (С. Воткінз, М. Дребл, Г. Грін); 3) психологічний аспект (Б. Дрейн, Ф. Перракіс); 4) культурологічний аспект (К. Фішбурн, Н. Хардін); 5) компаративістський підхід (Л. Скотт); 6) екофеміністичний підхід (Н. Елдіб); 7) педагогічний аспект (Т. Сперлінгер).

Теоретико-методологічну основу дослідження складають фундаментальні праці зарубіжних, вітчизняних i російських учених, присвячених творчості Д. Лессінг (М. Горлач, В. Крамар, М. Миколайчик, В. Луцик, О. Подкоритова), з теорії міфу (М. Ахундов, М. Еліаде, Ю. Лотман, О. Лосєв, Є. Мелетинський, В. Топоров), наукові напрацювання з теорії художнього часопростору (М. Бахтін, Д. Лихачов, Н. Копистянська, Ю. Лотман, В. Топоров).

Мета статті - виявити основні характеристики міфологічного простору в зазначених романах, дослідити взаємозв'язок із категорією міфологічного часу, що визначають авторську концепцію.

Специфіка досліджуваного матеріалу й характер поставлених завдань зумовлюють необхідність застосування комплексу методів, а саме: культурно-історичний метод, що уможливив визначення чинників впливу на творчість авторки в контексті доби; структурносемантичний метод, який дозволив дослідити особливості втілення категорії часу і простору в романах; міфокритичний підхід актуалізовано для визначення міфологічних елементів і специфіки образної системи у дилогії «Маара і Данн».

Наукова новизна дослідження полягає в тому, що здійснено комплексний аналіз часопросторових категорій романів Д. Лессінг «Маара і Данн», «Повість про генерала Данна, дочку Маари, Гріота та сніжного пса», а також виявлено структуротвірну функцію художнього часу в дилогії. Аналіз міфологічних аспектів означених творів письменниці поглибить розуміння специфіки художнього світу Д. Лессінг і визначить подальше вивчення сучасних творів англо-американських письменників, у текстах яких виявляються неоміфологічні риси.

Виклад основного матеріалу дослідження. Простір і час постають фундаментальними категоріями картини світу людини. Згідно концепції російського дослівника В. Топорова, простір є одним із найважливіших елементів міфопоетичної моделі світу. Науковець акцентує увагу на тому, що в архаїчній моделі світу простір не протиставлений часу як зовнішня форма споглядання внутрішній, оскільки простір і час є неподільними категоріями, що утворюють єдиний просторово-часовий континуум ${ }^{1}$. Архаїчний міфопоетичний простір протиставляється хаосу, виявляється деталізованим і заповненим речами. Дослідник підкреслює, що в часопросторовій єдності, міфологічному хронотопі, час згущується i стає новою формою простору, простір під впливом часу втягується в його рух, таким чином, відбувається так звана темпоралізація простору.

Російський вчений О. Подосинов, досліджуючи концепцію світосприйняття архаїчної людини, зазначає, що простір постає ментальною структурою. Людина сприймає всесвіт і розгортання простору від певного центру, тож, відповідно, вона виокремлює себе із загального ландшафту i співвідносить себе 3 певним центром. Науковець доходить висновків щодо егоцентричного світосприйняття простору архаїчною людиною, де «axis mundi» (вісь світу) - це сама людина ${ }^{2}$. Освоюючи довкілля, людина сприймала цей простір дуалістично, орієнтуючись на дві точки у просторі: центр і периферію. Відповідно, простір сприймався через бінарні опозиції «попереду - позаду», «ліворуч - праворуч», «верх - низ». «Попереду» сприймалося як видимий, безпечний простір, який вважався сакральним. В опозиції «попереду-позаду» складник «позаду» означав «за спиною», що таїло небезпеку й утілювало профанований простір. У бінарний опозиції «ліворуч - праворуч» складник «праворуч» також постає уособленням сакрального простору. Оскільки для більшості людей права рука є більш дієвою, відповідно, і простір, що знаходився по праву руку, сакралізувався частіше.

Дуалістичні просторові характеристики вплинули i на сприйняття часу, основним орієнтиром був щоденний схід і захід сонця. Північ асоціювалася з профанованим і небезпечним простором, світом мертвих, в якому відсутнє світло і неможливе існування. Південь співвідносився 3 «переднім» простором, де панувало сонце i життя. Тож, опозиція «схід - захід» корелює $з$ просторовою опозицією «правий - лівий».

Румунський дослідник М. Еліаде, вивчаючи категорію міфологічного часу в архаїчному суспільстві, зауважував, що людина архаїчного суспільства відчувала нерозривний зв'язок із Космосом і космічними ритмами. Науковець вважав, що час можна поділити на: 1) сакральний (у різних традиціях: Час , Міфічний Час, Час до часу, Час Сновидінь, Час до Падіння, Втрачений рай тощо; 2) профанований час (буденний) час. Сакральний час пов'язаний з природними, космічними ритмами, тоді як профанований час -3 історією. Оскільки космічні ритми циклічні і незворотні (сакральний час), а історія - лінійна і незворотна (профанований час), у свідомості людини архаїчного суспільства хоч і було присутнє поняття про незворотність подій, циклічність часу набуває превалюючого значення. Для сучасної людини знову-таки пропорція зворотна ${ }^{3}$.

М. Еліаде акцентує увагу на тому, що сакральний час пов'язаний з міфом, адже у повторенні міфу відновлюється у всій цілісності забутий час і, як наслідок, до певної міри людина стає «співучасником» згадуваних подій.

М. Мелетинський зазначає, що міфологічний час це не просто минуле, а особлива епоха першотворення, прачас, начальні, первинні часи, що передували початку відліку емпіричного часу ${ }^{4}$.

В дилогії Д. Лессінг «Маара і Данн» події відбуваються у далекому постапокаліптичному майбутньому на території континенту Африка, назву якого було змінено на Іфрик. Людство переживає глобальну катастрофу, що звела нанівець усі досягнення культури і «повернула» розвиток суспільства до первісного ладу. Письменниця

\footnotetext{
${ }^{1}$ Toporov V. N. Prostranstvo i tekst. Tekst: semantika i struktura [Space and Text: Semantics and Structure] Moscow, 1983 [in Russian].

${ }^{2}$ Dzhakson T. N. Konovalova I. G. Podosinov O. V Imagines mundi: antichnist i serednovichchya [Imagines mundi: antiquity and the Middle Ages], Moscow, 2013 [In Ukranian].

${ }^{3}$ Eliade M. Aspekty mifa [Aspects of the myth], Moscow, Invest, 1996 [In Russian].

${ }^{4}$ Meletinskiy E. M. ed. Mifologicheskiy slovar [Mythological dictionary], Moscow, Sovetskaya entsiklopediya, 1990 [in Russian].
} 
зображує події, що відбуваються у посушливій місцевості півдня, в якій відчуття часу героями постійно змінюється: його рух то розтягується, то пришвидшується. Сезонність виявляється основною одиницею виміру часу, в тексті відсутня співвіднесеність подій із днями тижня, місяцями, навіть зміни сезонів проходять непомітно, час вимірюється населенням континенту лише тривалими сезонами дощів, створюючи відчуття «застиглості» часу.

Континент, який «поринув» у безчасся, виявляє ознаки мертвого простору. Топоси півдня: Скальне селище, міста Рустам і Маджаб потерпають від засухи, їх поступово заносить піском, а величні споруди і міста минулого поволі зникають: «Посуха затягнулася і справи йдуть все гірше. Маджаб порожніє, про це біженці повідомляють. Там майже нікого не залишилося, в Маджабі. Рік тому ми над ним пролітали, бачили людей, було жваве місто, як Хелопс зараз. Але це в минулому» 5 .

Центральні ж регіони, якими $є$ міста Чарад і Білма, страждають від міжусобних війн. Подекуди зустрічаються кам'яні руїни стародавніх будов і сучасні споруди 3 дерева та глини. На півночі материка збереглися міста, подібні до архітектурних споруд минулого, що були збудовані переселенцями. Там ще збереглися «функціонуючі винаходи» попередніх поколінь: залізна дорога та вагонетки, водопровід тощо. Простір півдня, до якого належать Скальне селище, міста Маджаб і Хелопс, страждає від засухи, що відображає і кольорова гама. Превалюють відтінки жовтого кольору, які пов'язані з образом пекучого сонця, що знищує все живе. У цьому просторі домінують «Хтонічні» кореляти кольорів: буро-коричневий, іржавий, блідо-жовтий, сірий, чорний та червоний, про що свідчать пожухлі рослини, сухі русла річок та неродюча земля.

Головні герої роману, брат Данн і сестра Маара, переживають наслідки зупинення часу. Здійснюючи своєрідний квест - подорож з півдня на північ Африки, вони стають свідками постійних смертей навколо них і поступового «змертвіння» довкілля: «Попереду ще одна річка, теж швидка, теж повноводна. Вода підійшла до краю заростей, вимила в крутому береговому схилі печеру, оголила безліч білих палиць...кісток <..> в мертвій траві валялися кістки мертвих тварин». Ознаки потойбічного простору, що зустрічаються на початку шляху героїв (кістки мертвих тварин, мертва трава тощо), набувають символічного значення і наче «програмують» «змертвіння» довкілля. Згідно міфологічних уявлень, семантика «кісток» вважалась амбівалентною, оскільки вони уособлювали і буття (божественний вогонь), i смерть одночасно ${ }^{6}$. Збережені рештки кісток могли повернути істоту до життя, тож, символіка кісток співвідносилась не тільки 3 потойбічним світом, а й зі світом живих ${ }^{7}$.

Однак, зазначимо, що по мірі просування персонажів 3 півдня на північ хронотоп змінюється: кількість опадів, від яких безпосередньо залежать кліматичні умови на територіях материка, поступово збільшується.
На крайньому півдні ріка набуває сакрального значення, ii береги суворо охороняються, а ті, хто наважуються переступити священний кордон без дозволу або осквернити воду, жорстоко караються.

На півночі ж, навпаки, вода та водний простір взагалі втрачають своє сакрально-фундаментальне значення, характерне для півдня. Вода в цій місцевості втілює небезпеку: повені, наступаюче зледеніння, від якого тікали пращури, море як межа людських можливостей, що відділяє непізнанний простір від простору, опанованого людиною.

Таким чином, сакральний простір міста Рустам, Скального селища змінюється на профанований - міст Маджаб, Хелопс, Річні міста, Чарад. Про історію міста Рустам в тексті першої частини дилогії майже не згадується, відомо лише, що колись воно було столицею півдня Африки, та через громадянські війни Маара і Данн змушені були покинути це місто ще у дитинстві. Скальне селище, - у минулому окраїна Рустама, - місце для вигнанців, а тепер притулок для біженців, що поволі занепадає, перетворюючись на мертву пустелю, у якій повсюди зустрічаються предмети давнини («вічний» одяг, кістки химерних тварин, стара техніка, давні розвалини). Усі ці предмети викликають у місцевого населення жах, пошану, безсильну злість на могутність пращурів та власне безсилля.

У романному хронотопі відсутня точка відліку часу, немає конкретного зв'язку між визначенням часу i його переживанням: «До сотень років Маара звикла, як до чогось то дуже довгого, але відчутного, тоді як тисячі ще залишалися для неї чимось неймовірним, незбагненним, нескінченним» ${ }^{8}$. «Маара вимовила слово тисячі, бо чула його від Дейми, але не знала нічого, крім десяти пальців на руках та десяти на ногах. Вчили ії та ще чого то, вдома і в школі, але сотні і тисячі й інші слова чаклунське страшнувате число мільйон - означали для неї приблизно одне і те ж, безрозмірну невідомість» 9 .

У Скельному селищі одразу після появи брата i сестри починаються посушливі сезони. 3 кожним роком кількість опадів зменшується, і зрештою, жителі або втікають із селища на північ, або вмирають від нестачі води та інших ресурсів. Маара і Данн, покинувши Скальне селище, залишають за собою пустелю без жодного жителя, яка невдовзі спалахує вогнем. Тож, Скельне селище уособлює собою замкнений простір - люди не можуть його покинути, вони наче «прив'язані» до землі і лише смерть може їх «звільнити». Пожежа, яка спалахує в цьому просторі після втечі брата і сестри, набуває символічного значення. У міфологічній традиції вогонь - це символ очищення, відновлення. Полум'я караючий символ, персоніфікація влади божества над усім сущим. Вогонь символізує переродження, перехід до якісно нового стану. Пожежа, що займається у селищі - водночас і кара, і очищення, що змиє гріхи людства та знищить навіть згадку про існування життя в цьому регіоні.

У фіналі першої частини дилогії хронотоп знову набуває рис потойбіччя: мертвого, засніженого простору

\footnotetext{
${ }^{5}$ Lessing, D. Maara i Dann. [Mara i Dann], SPb., Amfora, 2008 [in Russian]. Moscow, Gumanit. izd. tsentr Vlados, 1996 [In Russian]. Moscow, LOKID - PRESS, 2005 [In Russian].

${ }^{8}$ Lessing D. Maara i Dann [Mara i Dann], SPb., Amfora, 2008 [in Russian].

${ }^{9}$ Ibidem, P. 189
}

${ }^{6}$ Makovskiy M. M. Sravnitelnyy slovar mifologicheskoy simvoliki $v$ indoyevropeyskikh yazykakh: Obraz mira i miry obrazov [Comparative dictionary of mythological symbols in Indo-European languages: The image of the world and the worlds of images],

${ }^{7}$ Bagdasaryan V. E., Orlov I. B., Telitsyn V. L Simvoly. znaki. emblemy: Entsiklopediya [Symbols, signs, emblems: Encyclopedia], 
(Центр, Тундра). Перебуваючи у Скальному селищі, Маара часто відвідує покинуте місто, навіть назва якого не збереглася. У Покинутому місті головна героїня розглядала давні фрески, на яких було відображено крах поколінь якоїсь цивілізації. Давнє Місто пережило декілька катастроф: землетруси, ворожі напади, пожежі тощо. Однак на руїнах зруйнованого міста декілька разів поспіль будувалося нове, пишніше та багатше за попереднє. Люди, що відновлювали побудову, навіть не підозрювали про наявність руїн, що залишилися від пращурів: «В іншому місці Маара знайшла руїни споруди, напівзасипані стіни якої зсередини прикрашали рельєфи <..>. Насправді ж будівельник верхньої стіни не знав про існування нижньої, похованої під шаром землі, не цікавився нею. А згодом земля обсипалася, ії змили зливи, і з'явилась настільки химерна комбінація» ${ }^{10}$.

Таким чином, сучасне місто ніби «нашаровувалось» на попереднє: нащадки відбудовували на руїнах попереднього міста нове, таким чином, його межі розширювалися, допоки невідома катастрофа не змусила жителів втекти, не відбудовуючи його заново. Жителі Скального селища не наважувались приходити до цієї покинутої місцевості, вони жахалися і уникали привидів, що за місцевими повір'ями мешкали там. Навіть крокодили, яких місцеве населення називало «драконами», не наважувались перетинати священний кордон - круту кручу та скали, що пригнічували своєю висотою. Густий та колючий чагарник заважав іншим сміливцям пробратися до священного місця. Цей простір мертвий, нащадки людей, що тут жили, давно покинули це місце, час тут остаточно зупинився.

Художня концепція часу виявляє міфологічні риси: міфологічний характер часу в дилогії актуалізується у циклічності й неоднорідності (розтягненості/ ущільненості) плину романного часу. Циклічність як одна 3 характерних рис міфологічного часу втілюється в романі через образ зруйнованого давнього міста. На рештках попередніх споруд будували нові, цикл розквіту та падіння окремої громади декілька разів повторювався, допоки останні жителі не померли або залишили свою домівку. Простежується повторюваність, притаманна космогонічним міфам: повернення до часів Хаосу і впорядкування його в організований Космос.

У тексті твору катастрофа, що знищила майже повністю все людство, виявляється незворотною карою за гріхи людські. Устремління проникнути до сакрального часу $є$ своєрідною спробою повернути «золоті часи» буття, відновити втрачені знання, а відтак повернути цивілізацію і владу над світом.

Хронотоп другої частини дилогії, романі «Повість про генерала Данна, дочку Маари, Гріота та сніжного пса», відрізняється від часопростору першого роману. Бінарні опозиції «північ-південь» проявляються в ньому більш імпліцитно: відсутній різкий контраст зображення топосів, що було характерно для першої частини дилогії. 3'являються поняття «схід» і «захід». Стає відомо, що на сході йдуть нескінченні війни і безперервний потік біженців збирається в Центрі. Захід зображується як кордон відомого світу - континент омивається однойменним морем, за межами якого - невідомий і небезпечний простір: «На заході Серединного моря Данн знай- шов Скельні ворота <..> На протилежному кінці моря, на сході, було написано слово «Незвідане» ${ }^{11}$.

Таким чином, герої романів замкнені в обмеженому просторі материка, вийти за кордони якого неможливо: «А той не міг більше зробити ні кроку, неначе шлях на захід був закритий, затягнутий темною хмарою всемогутнім словом «ні» ${ }^{12}$.

Сакральним центром світобудови постає однойменне місто на півночі материка. Однак, місто потерпіло крах і більш не в змозі виконувати покладені на нього функції. Таким чином, простір дилогії не має священного центру, а отже є безцентровим і виявляється таким, що поринув у хаос. Попередня столиця материка відтепер слугує лише своєрідною пам'яткою, монументом величі минулого. Простір міста насичений предметами давнини - винаходами пращурів, які для сучасного покоління набувають сакрального значення. Своєрідним «серцем» міста $\epsilon$ підземна бібліотека, де зберігаються найцінніші книжки, що сховані у скляному кубі. Священні давні книги є ключем для порятунку - лише порятунок цих книжок зробить можливим побудову нового центру світобудови, а відтак і «відродження» людства.

Художній простір романів зображено в аспекті егоцентризму - індивід виокремлює себе із навколишнього довкілля сприймає простір навколо себе дуалістично, «опановуючи» його за допомогою протиставлення міфологічних оппозицій «свій-чужий», «хаос-космос», «центр-периферія». Романному простору притаманні гетерогенні характеристики, що актуалізуються через такі бінарні опозиції, як «північ-південь», «живиймертвий», «небезпечний-безпечний», «правий-лівий», «сакральний- профанований», «відкритий-закритий».

Просторова опозиція «північ - південь» кардинально змінює своє аксіологічне значення: традиційно північ асоціюється із профанованим і небезпечним простором, світом мертвих, в якому відсутнє світло і неможливе існування. Південь згідно міфологічному сприйняттю співвідноситься з «переднім» простором, де панує сонце і життя. Відтепер південь утілює у собі небезпеку, виявляючи ознаки потойбічного простору, в якому неможливе існування жодної живої душі, у той час як північ постає життєдайним началом, «колискою життя». Саме на півночі розташоване сакральне місто, саме там зберігаються священні знання, за допомогою яких $є$ надія відродити цивілізацію. У художньому контексті дилогії присутне відчуття безчасся, «вічне» сонце, «нескінченна» пустеля.

Центр, що був у минулому столицею усього Іфрику, з часом втрачає свою значущість і владу над територією материка і не може виконувати покладені на нього функції. Відсутність сакрального центру спричинила занепад, хаос і призупинення часу. Оскільки виходу із замкненого простору не існує, а отже іншого центру, під «тінню» якого можна було б побудувати нову цивілізацію немає, виникає потреба або у відродженні старого центру, або у побудові нового. Кольорова гама, що характеризує часо-просторовий континуум дилогії, також набуває аксіологічного значення. Опозиції «північпівдень» актуалізовано за допомогою кольорових корелятів жовтого, буро-коричневого, іржавого - для півдня і синього, зеленого, білого, синього - для півночі.

\footnotetext{
${ }^{10}$ Lessing D. Maara i Dann [Mara i Dann], SPb., Amfora, 2008 [in Russian].

${ }^{11}$ Lessing D. Povest o generale Danne, docheri Maary. Griote i snezhnom pse [The Story of General Dann, Mara`s daughter, Griot and the Snow Dog], SPb., Amfora, TID Amfora, 2008 [in Russian].

${ }^{12}$ Ibidem, P. 95.
} 
Головні герої романів Д. Лессінг «замкнені» у просторі, вони змушені шукати сакральний центр світобудови, щоб відновити втрачене знання та повернути собі владу над світом, пройти процес «індивідуації» (Дж. Кемпелл), щоб віднайти «самість» (К. Г. Юнг).

Перспективу дослідження вбачаємо у подальшому вивченні неоміфілогічних аспектів романної творчості Д. Лессінг, що поглибить розуміння специфіки художнього світу творів письменниці і визначить перспективи вивчення сучасної англійської літератури.

Kravets Olena, Proskurina Nataliia Features of the mythological space in Doris Lessing`s dilogy "Mara and Dann". The article is devoted to the study the literary heritage of contemporary English writer, Nobel laureate, Doris Lessing. Author Creativity is a complex literary phenomenon, which researchers associate with the canons of postmodern literature.

The object of literary research are the novels "Mara and Dann", "The Story of General Dann and Mara's Daughter, Griot and the Snow Dog", which belong to the late period of D. Lessing's creativity. The purpose of the article is to investigate the mythological features of artistic space and time, which determine the author's concept of the artistic picture of the world in the dilogy.

The specific nature of the material of the study and the nature of the tasks necessitate using a set of methods: a cultural-historical method that made it possible to determine the factors influencing the author's work in the context of the period; structural-semantic metho$\mathrm{d}$, which allowed to explore the features of the embodiment of the categories of time and space in novels; the mythocritical approach is actualized for the definition of mythological elements and the specific features of the image system in the "Mara and Dann" dilogy.

As a result of the analysis of the D. Lessing 's novels it is concluded that the mythological space of the writer's novels has heterogeneous characteristics that are actualized through binary oppositions such as "north-south", "living-dead", "sacred-profane", "dangerous -safe", "right-left", "open-closed". The chronotope of the second part of the dilogy, "The Story of General Dann and Mara's Daughter, Griot and the Snow Dog" differs from the space-time continuum of the first novel. The binary oppositions "north-south" appear more implicitly in it, there is no sharp contrast in the image of topos, which is a characteristic feature of the first part of the dilogy.

The novel chronotope inherent peculiarity is a cyclical concept of time, which is typical for the mythological tradition. Novel events occur in the distant post-apocalyptic future, on the territory of the continent of Ifrik. Humanity is experiencing a global catastrophe, which destroyed all the achievements of culture and terminated development. The main characters of the D. Lessing dilogy are situated in the "closed" space of the continent, they are forced to seek the sacred center of the universe in order to restore the lost knowledge of generations and regain power over the world, go through the process of "individuation" in order to gain "self".

The scientific novelty of the study is that a complex analysis of the space-temporal categories of the D. Lessing dilogy was carried out, as well as the structure-forming function of artistic time in novels. The analysis of the mythological aspects of the writer's dilogy will deepen the understanding of the specifics of D. Lessing artistic world, whose work reflects the neomythological tendencies of English literature of the XX - XXI centuries, and will outline the vectors for further study of the works of contemporary Anglo-American writers whose works show neomifological features.

Key words: D. Lessing, neomythologism, novel, mythological space, mythological time

Кравець Олена - кандидат філологічних наук, дочент кафедри історії зарубіжної літератури Харківського національного університету імені В.Н. Каразіна. Автор близько 30 наукових та навчально-методичних прачь. Наукові інтереси: зарубіжна література XX-XXI століть, англоамериканська література XX-XXI століть, проблеми неоміфологізму, мультикультуралізму.

Kravets Olena - Candidate of Philology, Associate Professor of History of Foreign Literature and Classical Philology Department of Kharkiv V. N. Karazin National University. An author of about 30 scientific and educational works. Her research interests: Foreign Literature of the XX-XXI centuries, Anglo-American Literature of the $X X-X X I$ centuries, problems of neomythologism, multiculturalism.

Проскуріна Наталія Юріївна-магістр філологічного факультету Харківського національного університету імені $B$. H. Каразіна. Наукові інтереси: зарубіжна література XXХХІ століть, проблеми неоміфологізму.

Proskurina Nataliia - Master of Philology of History of Foreign Literature and Classical Philology Department of Kharkiv $V$. N. Karazin National University. Her research interests: Foreign Literature of the XX-XXI centuries, problems of neomythologism.

Received: 20.06 .2018

Advance Access Published: August, 2018

(C) O. Kravets, N. Proskurina, 2018 